\title{
Improvement of lipid and phospholipid recoveries from sardine (Sardina pilchardus) viscera using industrial proteases
}

\author{
J. Dumay ${ }^{a,{ }^{*}}$, C. Donnay-Moreno ${ }^{a}$, G. Barnathan ${ }^{b}$, P. Jaouen $^{c}$ and J.P. Bergé ${ }^{a}$ \\ IFREMER, BP 21105, F 44311 Nantes, France \\ 'Université de Nantes, Nantes Atlantique Universités, SMAB, EA2160 Faculté de pharmacie, France \\ ${ }^{c}$ GEPEA, UMR-CNRS 6144, Samt-Nazaire, France \\ *: Corresponding author: Fax: +33 2403740 71; email : jdumay@ifremer.fr
}

\begin{abstract}
Enzymatic hydrolysis of sardine viscera by three broad spectrum proteases was investigated using the pHstat method $\left(24 \mathrm{~h}, \mathrm{pH} 8,50^{\circ} \mathrm{C}\right)$. After hydrolysis, three fractions (sludge, aqueous phase and oily phase) were collected. For each fraction, lipids and phospholipids were quantified and molecular weights of aqueous phase peptides were determined. Under these conditions, the degree of hydrolysis (DH) varied from 1.9\% (Flavourzyme), 3.1\% (Protamex) and to 3.3\% (Alcalase). Dry matter distribution indicated that all hydrolysis performed increased solubilisation of proteins: protein recovery for each hydrolysis ranged from $57.4 \%$ to $61.2 \%$. Furthermore, the total lipid content in the liquid parts (oily and aqueous phases) increased (at least $85 \%$ of lipids quantified in the raw material are in these phases) which may improve lipid recovery for commercial applications. In addition, these lipids were richer in phospholipids than those extracted by classical chemical extraction, especially after Alcalase hydrolysis.
\end{abstract}

Keywords: Phospholipid; Hydrolysis; Lipid; By-product; Sardine; Fish protein hydrolysate (FPH) 


\section{Introduction}

According to the recent Food and Agriculture Organization (FAO) report on bycatch and discards, the weighted discard is estimated at $8 \%$, and the yearly average discards are estimated to be 7.3 million tons [1]. While bycatch has declined over the last few years, largely due to more selective fisheries and regulations, there is still great opportunity to reduce bycatch losses. The growing market for bycatch products for human or animal food is due to improved processing technologies and expanding market opportunities for lower-value catch. Worldwide, total landings of small pelagics (sardine, mackerel and horse mackerel) are about 4 million tons leading to about 50,000 tons of discards.

In addition to their nutritional value [2], phospholipids have also exhibited antibacterial [3], antiviral [4-6] and antitumoral [7-9] activities. Currently, phospholipids can be obtained from natural sources (oil seeds and egg) [10] or produced by synthesis (Larodan Fine Chemicals, Malmö, Sweden ; Avanti Polar Lipid, Alabaster, Alabama for example). Although natural phospholipids have been shown to be more bioactive than synthetic ones, the extraction procedures (involving organic solvents and chromatography) are quite expensive and not environmentally sound. Though production of synthetic phospholipids is theoretically cheaper and less polluting, they are not currently produced at an industrial scale. Thus, the improvement of lipid extraction techniques from fishing discards offers a large opportunity to reduce waste and increase profit from a highly valuable by-product. 
Enzymatic tissue disruption may be a valid alternative technique for releasing natural lipids from fish. Previous studies have shown that, when compared to classical organic extraction, lipid extraction is enhanced by a pre-hydrolysis step using widespectrum proteases [11] and a part of the oil could be obtained after hydrolysis and centrifugation [12]. Furthermore, peptides generated during hydrolysis could also be upgraded.

Industry is becoming more and more interested in Fish Protein Hydrolysates (FPH) for a variety of applications and properties [13-25].

The objectives of this work were to evaluate solvent-free lipid and phospholipid extractions using three commercial enzymes (Protamex, Alcalase and Flavourzyme) and to pinpoint possible uses for these lipids and associated FPH, in order to provide basic knowledge for further studies.

\section{Material and methods}

All analyses were performed in triplicates.

\subsection{Materials}

Sardines (Sardina pilchardus) were provided by Pêcheries Océanes (Nantes, France) and were caught in the North East Atlantic in April and June 2004. Fish were stored in ice and filleted less than $12 \mathrm{~h}$ after catch. Viscera were collected and stored under vacuum at $-80^{\circ} \mathrm{C}$. Due to high variation in chemical composition of fish according to season, sex and length [26;27], samples coming from April and June were mixed 
together and homogenized with a blender (Waring Commercial, USA) for $1 \mathrm{~min}$. Samples were then stored at $-80^{\circ} \mathrm{C}$.

Enzymes used for hydrolysis were provided by Novozymes AS (Denmark). Alcalase 2.4 L FG (EC number : 3.4.21.62) is a bacterial serine endopeptidase prepared from a strain of Bacillus lichenformis. Protamex (EC numbers: 3.4.21.62 and 3.4.24.28) is a Bacillus protease complex. Flavourzyme $500 \mathrm{MG}$ (EC number: 3.4.11.1) is a fungal protease/peptidase complex produced by submerged fermentation of a selected strain of Aspergillus oryzae. It contains both endoprotease and exoprotease activities.

\subsection{Hydrolysis}

Mixed by-products were homogenized with water (ratio 1/1, w/v). For optimal enzyme activity, the mixture was adjusted to $\mathrm{pH} 8$ (with $\mathrm{NaOH} 1 \mathrm{M}$ ) and maintained at $50^{\circ} \mathrm{C}$ in a water bath. Enzyme $(0.1 \% \mathrm{w} / \mathrm{w}$ for Alcalase and Protamex and $1.5 \% \mathrm{w} / \mathrm{w}$ for Flavourzyme) was added to the mixture and the system was continuously stirred at 300 rpm for 24 h. $\mathrm{pH}$ and temperature were monitored according to the pHstat method (TIM 854, Radiometer analytical, SAS, France) with addition of a solution of $\mathrm{NaOH} 1 \mathrm{M}$. Thus, the degree of hydrolysis (DH) could be obtained following the formula:

$$
D H=\frac{V \cdot M \cdot 100}{\alpha \cdot m p \cdot h_{t o t}}
$$

Where V: volume $(\mathrm{mL})$ of sodium hydroxide consumed during hydrolysis

M: molarity of sodium hydroxide

$\alpha$ : dissociation factor for $\alpha-\mathrm{NH}_{2}$ groups $=0.88$ at $50^{\circ} \mathrm{C}$ [28] 
$\mathrm{mp}$ : mass $(\mathrm{g})$ of protein in the raw material introduced in the system (protein content was determined according to Crooke et al. [29])

$\mathrm{h}_{\text {tot }}:$ total number of peptide bonds in the protein $=8,6$ eq.g. $\mathrm{kg}^{-1}$ protein in fish samples [30]

The extent of enzymatic hydrolysis was determined by the cleavage of peptide bonds during proteolysis. The DH is defined as the ratio between the total number of peptide bonds cleaved and the total number of peptide bonds in the protein substrate, expressed as a percentage [31].

After hydrolysis, the temperature was increased to $80^{\circ} \mathrm{C}$ for 10 min to inactivate the enzyme, as specified by the manufacturer [32]. The hydrolysate was then centrifuged at $17,600 \mathrm{~g}$ for $30 \mathrm{~min}$. Three fractions were then collected: sludge, oily phase and aqueous (soluble) phase. Each fraction was then freeze-dried and stored at $-20^{\circ} \mathrm{C}$ until analysis.

\subsection{Lipid extraction}

Lipid extraction was carried out according to the Folch procedure [33]. Lipids were weighed and results expressed as g of lipid / g of dry matter. The lipid extracts were kept in $10 \mathrm{~mL}$ chloroform and stored at $-80^{\circ} \mathrm{C}$ until analysis.

\subsection{Phospholipid content of total lipid extract}

Phospholipid content was evaluated by a colorimetric method [34] based on the formation of a complex between phospholipids and ammonium ferrothiocyanate. A 
standard curve was plotted with standard phosphatidylcholine in chloroform (5 to 50 $\mu \mathrm{g} / \mathrm{mL}$ ) and results were expressed as g phosphatidylcholine equivalents / $\mathrm{g}$ of dry matter.

\subsection{Analyses}

Molecular weight distribution in the protein hydrolysates was estimated by gel filtration chromatography on a FPLC Superdex 75 HR 10/30 column (Pharmacia Biotech): exclusion size range of 3,000 to $70,000 \mathrm{Da}$, eluting solvent: $5 \%$ acetonitrile / $0.1 \%$ trifluoroacetic acid / $\mathrm{NaOH} 50 \mathrm{mM}$ buffer, flow rate: $0.5 \mathrm{~mL} / \mathrm{min}$, absorbance: 214 $\mathrm{nm}$. Standards injected were ribonuclease (13,700 Da), chymotrypsinogen A (25,000 Da), ovalbumin (43,000 Da) and albumin (67,000 Da).

Crude protein content $(\mathrm{N} \times 6.25)$ was estimated in the raw material and the aqueous phase from hydrolysis and determined colorimetrically after Kjeldahl digestion using a method described by Crooke et al. [29].

Dry matter content was estimated gravimetrically after freeze-drying, and ash content by heating samples at $600^{\circ} \mathrm{C}$ overnight.

\subsection{Statistical analysis}

The analysis of variance (ANOVA) and Fischer tests were carried out by Statgraphics Plus (Manugistics Inc, U.S.A.).

\section{Results and discussion}

The proximate chemical composition of sardine's viscera was : $77.65 \pm 0.0 \%$ moisture; $1.9 \pm 0.0 \%$ ash; $4.9 \pm 0.1 \%$ lipids and $15.8 \pm 1.1 \%$ proteins.

\subsection{Hydrolysis}


DH results for Protamex, Alcalase and Flavourzyme were 3.1, 3.3 and 1.9\%, respectively. It appears that the $\mathrm{DH}$ was correlated to the proteolytic activity of each enzyme (592, 1956 and $276 \mu \mathrm{g}$ BSA cut per hour at $\mathrm{pH} 8$ and at $50^{\circ} \mathrm{C}$, respectively). Hence, Alcalase, which has the highest activity, also had the highest DH, followed by Protamex and Flavourzyme. DH results obtained were in the same range (not more than $5 \%$ variation) as those previously obtained on sardine with Alcalase $0.1 \%$ even under different hydrolysis conditions [15;21]. Nevertheless, higher DH have been obtained on other fish species [20;23;25], notably after hydrolysis optimization using statistical models (such as experimental design) [25;35] This was not the case here where hydrolysis was carried out under optimum conditions for enzymes determined in model system (hemoglobin hydrolysis), and it is well known that these conditions change with the substrate.

Without hydrolysis (i.e. in the crude viscera), after the centrifugation step, $46 \%$ of the dry matter was located in the soluble phase, while $30 \%$ was recovered in the oily phase and $24 \%$ in the insoluble part (Fig. 1). After conducting hydrolysis on viscera samples, the dry matter distribution was quite similar regardless of the enzyme used (about $9 \%$ in insoluble part, $11 \%$ in oily phase and $80 \%$ in soluble fraction). So, dry matter content of the soluble part rose during hydrolysis, while the dry matter content of the oily phase decreased. However, the total lipid content was higher with hydrolysis, which means that the oily phase was richer in lipids after conducting an hydrolysis. Thus, the disruption of tissues increased lipid liberation compare to a classical extraction. These results also indicate that a large part of material was solubilised during hydrolysis, mainly proteins but also lipids. Thus, in addition to solubilising proteins, hydrolysis could 
improve the quality of the oil phase. A recent study on hydrolysis of cod viscera [36] also showed high solubilisation of the dry matter under similar conditions ( 24 h hydrolysis at $55^{\circ} \mathrm{C}$ with Alcalase and Protamex, only $\mathrm{pH}$ and $\mathrm{pH}$ control were different). Thus, the solubilisation of matter appears independent of high DH values. As lipid content in the aqueous phase of the raw material was $4 \%$, the proportion of lipids after hydrolysis was around $20 \%$. This shows that lipid contents of aqueous and oily fractions were increased after hydrolysis regardless of the enzyme used. On the contrary, the constant lipid content of sludges (around 30\%) with or without hydrolysis indicated that this fraction could be considered as the non-hydrolyzed fraction. Protein recoveries and protein contents in soluble fraction after hydrolysis are given in Table I. After 24 hours of hydrolysis, protein recoveries in soluble parts were in the range of $57.4-61.2 \%$. Despite the low $\mathrm{DH}$ obtained $(1.9-3.3 \%)$, such results are similar to those obtained in other studies on byproduct hydrolysis [20;37]. However, aqueous phases obtained were rich in proteins (about $50 \%$ ).

\subsection{Lipid content}

After hydrolysis, lipid content was higher than those obtained without enzymatic treatment (Fig. 2). The lipids ratio (lipids in sludge + lipids in oily fraction + lipid in aqueous fraction / lipids of non hydrolyzed material) was quite similar for Protamex and Alcalase (1.37 and 1.39, respectively), while Flavourzyme gave higher values (1.52). However, no statistical difference was found among the three enzymes and two clusters could be identified, one with the classical extraction and the second one with the three enzymatic treatments. These expected results reveal that even with precautions taken such as pre-incubation phase of fresh tissues with a polar solvent and a vigorous mixing 
before adding less polar solvent, the lipid extraction was not complete with classical organic extraction. The additional lipids obtained by using proteolytic enzymes were probably among the most difficult to extract by classical methods. While a second extraction could enhance the yield of extraction, this is more solvent- and time- intensive [38].

According to statistical analysis, lipid distribution were similar regardless of the proteases used. Thus, soluble fractions contained the greatest part of lipids (50-60\%) followed by the oily phases (32-39\%), while sludges possessed only 8 to $12 \%$ of the total lipids quantified. Lipids contained in liquid fractions (oily and soluble ones) could be purified by solvent-free steps (such as filtration or refining). Thus, around $90 \%$ of total lipids could be recovered using sustainable processes, i.e. without the use of solvents. Furthermore, aqueous phases could be up-graded, as feed (due to their high nutritional value), food ingredient, nitrogen source in microbial growth media or for their bioactive properties [13-25]. In most of the cases, those applications have been established with high protein and low lipid contents products. Thus, fat removal has to be performed by additional processes such as filtration on specific membranes.

\subsection{Phospholipid content}

Regarding phospholipid distribution (Fig. 3), it appears that enzymatic hydrolysis with Flavourzyme did not lead to a higher extraction of phospholipids when compared to classical procedure. However, hydrolysis of the raw material by Protamex or Alcalase seems to improve phospholipid extraction (increasing factor of 1.75 and 2.82 for Protamex and Alcalase respectively). 
The main portion of the phospholipids was located in the soluble fraction $(68 \%$ for Flavourzyme and $74 \%$ for Alcalase and Protamex), while oily fraction and sludge contain less than $20 \%$ each. Thus, as mentioned earlier, phospholipids could also be further isolated without using solvents (for example with membranes). Such phospholipid-enriched fraction could be screened for biological activities [3-9]. At least, such products could be used in food or feed as these lipids are known to offer health benefits [2]. For example, in aquaculture, larval feed is supplemented with phospholipids which appear essential for good development [39].

\subsection{Peptides molecular weight distribution}

The relative low DH (less than 4\%) obtained even after 24-hours hydrolysis did not result in a high modification of the molecular weight distribution in our FPH in comparison to the one of the raw material (Fig. 4). However, it should be noted that only soluble peptides and proteins were analyzed here.

It is well known that shortening protein reduce their functional properties (emulsification, solubility, low bitterness...) $[15 ; 16 ; 19]$. On the other hand, cutting protein in peptides could reveal biological activities [14;21;40], and in some cases, the shorter they are the more active they will be [24]. So, a choice has to be made between biological and functional properties in order to identify the most valuable possible products.

\section{Conclusion}

This work demonstrates the usefulness of enzymatic hydrolysis for up-grading fishing industry by-products such as sardine viscera. Thus, in addition to the well-known 
valuable FPH products, lipidic compounds can also be recovered by a sustainable process such as enzymatic hydrolysis and membrane technology. To the best of our knowledge, this study was the first to demonstrate how industrially-available wide-spectrum proteases enhance the extractability of lipidic compounds from tissues. In addition, these lipids are recovered in liquid phases included the most polar ones i.e. phospholipids. This phenomenon is observed regardless of the enzyme used (Protamex, Alcalase and Flavourzyme). Finally, these results, notably the increase of total lipids after prehydrolysis step, indicate that the classic organic solvent extraction methods used by most analysts underestimates the amount of lipids in tissues. A secondary extraction or a enzymatic are ways of better estimating the real lipid content in tissues.

\section{Acknowledgements}

This work was performed using the SiobioCle LIMS (Chatou, France). Authors also want to thanks to the Euro Seafood Trading Company (France) for providing $\mathrm{PhD}$ grant for this research. This work was performed within the Integrated Research Project SEAFOODplus, contract No FOOD-CT-2004-506359. The partial financing of the work by the European Union is gratefully acknowledged.

\section{References}

1. FAO, Discards in the world's marine fisheries: an update. 2004.

2. Schneider, M., Phospholipids for functional food. Eur. J. Lipid Sci. Technol., 2001, 103 98-101.

3. Tamehiro, N., Okamoto-Hosoya, Y., Okamoto, S., Ubukata, M., Hamada, M., Naganawa, H., Ochi, K., Bacilysocin, a novel nhospholipid nntibiotic nroduced by Bacillus subtilis 168. Antimicrob. Agents Ch., 2002, 46 315-20.

4. Cheng, L., Hostetler, K. Y., Chaidhawangul, S., Gardner, M. F., Beadle, J. R., 
Keefe, K. S., Bergeron-Lynn, G., Severson, G. M., Soules, K. A., Mueller, A. J., Freeman, W. R., Intravitreal toxicology and duration of efficacy of a novel antiviral lipid prodrug of ganciclovir in liposome formulation. Invest. Ophth. Vis. Sci., 2000, 41 1523-31.

5. Hostetler, K. Y., Richman, D. D., Sridhar, C. N., Felgner, P. L., Felgner, J., Ricci, J., Gardner, M. F., Selleseth, D. W., Ellis, M. N., Phosphatidylazidothimidine and phosphatidyl-ddC: assessment of uptake in mouse lymphoid tissue and antiviral activities in human immunodefiency virus-infected cells and in Rauscher leukemia virus-infected mice. Antimicrob. Agents Ch., 1994, 38 2792-7.

6. Hostetler, K. Y., Korba, B. E., Sridhar, C. N., Gardner, M. F., Antiviral activity of phosphatidyl-dideoxycitidine in hepatitis B-infected cells and enhanced hepatic uptake in mice. Antivir. Res., 1994, 24 59-67.

7. Murakami-Murofushi, K., Kobayashi, S., Onimura, K., Matsumoto, M., Shioda, M., Yoshida, S., Shoji, M., Murofushi, H., Selective inhibition of DNA polymerasealpha family with chemically synthesized derivatives of PHYLPA, a unique Physarum lysophosphatidic acid. Biochim. Biophys. Acta, 1995, 1258 57-60.

8. Fischer, D. J., Liliom, K., Guo, Z., Nusser, N., Virag, T., Murakami-Murofushi, K., Kobayashi, S., Erickson, J. R., Sun, G., Miller, D. D., Tigyi G., Naturally occurring analogs of lysophosphatidic acid elicit different cellular responses through selective activation of multiple receptor subtypes. Mol. Pharmacol. , 1998, 54 979-88.

9. Murakami, M., Makabe, K., Okada, S., Yamaguchi, K., Konosu, S., Screening of biologically active compounds in microalgae. Nippon Suisan Gakk., 1988, 54 10359.

10. Peng, L., Xu, X., Mu, H., Høy, C. E., Adler-Nissen, J., Production of structured phospholipids by lipase-catalyzed acidolysis: optimization using response surface methodology. Enzyme and Microb; Tech., 2002, 31 523-32.

11. Dumay, J., Barthomeuf, C., Bergé, J. P., How enzymes may be helpful for upgrading fish by-products: enhancement of fat extraction. J. Aquatic Fish Product Technol., 2004, 13 69-84.

12. Šliźyte, R., Daukšas, E., Falch, E., Storrø, I., Rustad, T., Yield and composition of different fractions obtained after enzymatic hydrolysis of cod (Gadus morhua) byproducts. Process Biochem., 2005, 1415-24.

13. Guérard, F., Guimas, L., Binet, A., Production of tuna waste hydrolysates by a commercial neutral protease preparation. J. Mol. Catal. B-Enzym., 2002, 19-20 48998.

14. Guérard, F., Dufossé, L., De La Broise, D., Binet, A., Enzymatic hydrolysis of protein from yellowfin tuna (Thunnus albacares) wastes using alcalase. J. Mol. Catal. B-Enzym., 2001, 11 1051-9. 
15. Quaglia, G. B., Orban, E., Influence of enzymatic hydrolysis on structure and emulsifying properties of sardine (Sardina pilchardus) protein hydrolysate. J. Food Sci., 1990, 55 1571-3.

16. Gildberg, A., Enzymic processing of marine raw materials. Process Biochem., 1993, 28 1-15.

17. Mackie, I. M., General review of fish protein hydrolysates. Anim. Feed Sci. Tech., 1982, 7 113-24.

18. Mackie, I. M., Proteolytic enzymes in recovery of proteins from fish waste. Process Biochem., 1978, 12 12-4.

19. Quaglia, G. B., Orban, E., Influence of the degree of hydrolysis on the solubility of the protein hydrolysates from sardine (Sardina pilchardus). J. Sci. Food Agric., 1987, 38 271-6.

20. Liaset, B., Lied, E., Espe, M, Enzymatic hydrolysis of by-products from the fishfilleting industry; chemical characterization and nutritional evaluation. J. Sci. Food Agric., 2000, 80 881-9.

21. Ravallec-Plé, R., Charlot, C., Pires, C., Braga, V., Batista, I., Van Wormhoudt, A., Le Gal, Y., Fouchereau-Péron, M., The presence of bioactive peptides in hydrolysates prepared from processing waste of sardine (Sardina pilchardus). $J$. Sci. Food Agric., 2001, 81 1120-5.

22. Kristinsson, H., Rasco, B. A., Fish protein hydrolysates: Production, biochemical, and functional properties. Crit. Rev. Food Sci., 2000, 40 43-81.

23. Liaset, B., Julsham, K., Espe, M., Chemical composition and theoretical nutritional evaluation of the produced fractions from enzymic hydrolysis of salmon frames with Protamex. Process Biochem., 2003, 38 1747-59.

24. Je J. Y ., Park, P. J., Kim, S. K., Antioxydant activity of a peptide isolated from Alaska pollack (Theraga chalcogramma) frame protein hydrolysate. Food Res. Int., 2005, 38 45-50.

25. Nilsang, S., Lertsiri, S., Suphantharika, M., Assavanig, A., Optimization of enzymatic hydrolysis of fish soluble concentrate by commercial proteases. J. Food Eng., 2005, 70 571-8.

26. Silva, A., Morphometric variation among sardine (Sardina pilchardus) populations from the northeastern and the western Mediterranean. ICES J. Mar. Sci., 2003, 60 1352-60.

27. Caponio, F., Lestingi, A., Bilanca, M. T., Laudadio, V., Chemical characteristics and lipid fraction quality of sardines (Sardina pilchardus W.): influence of sex and length. J. Appl. Ichtyol., 2004, 20 530-5. 
28. Adler-Nissen, J., Enzymic hydrolysis of food proteins. New York: Elsevier, Applied Science Publishers. , 1986, 110-69.

29. Crooke, W. M., Simpson, W. E., Determination of ammonium in Kjeldahl digests of crops by an automated procedure. J. Agric. Food Chem., 1971, 27 1256-62.

30. Novozymes, Determination of the Degree of Hydrolysis (DH) based on OPA reaction. Novozymes, 2001.

31. Ravallec-Plé, R., Gilmartin, L., Van Wormhoudt, A., Le Gal, Y., Influence of the hydrolysis process on the biological activities of protein hydrolysates from cod (Gadus morhua) muscle. J. Sci. Food Agric., 2000, 80 1-5.

32. Novozymes, Alcalase food grade. Product sheet, 2001.

33. Folch, J., Lees, M., Sloan Stanley, G. H., A simple method for the isolation and purification of total lipids from animal tissues. J. Biol. Chem., 1957, 226 497-509.

34. Stewart, J. C. M., Colorimetric determination of phospholipids with ammonium ferrothiocyanate. Anal. Biochem., 1980, 104 10-4.

35. Simpson, B. K., Nayeri, G., Yaylayan, V., Ashie, I. N. A., Enzymatic hydrolysis of shrimp meat. Food Chem., 1998, 61 131-8.

36. Aspmo, S. I., Horn, S. J., Eijsink, V. G. H., Enzymatic hydrolysis of Atlantic cod (Gadus morhua L.) viscera. Process Biochem., 2005, 40 1957-66.

37. Gildberg, A., Stenberg, E., A new process for advanced utilisation of shrimp waste. Process Biochem., 2001, 36 809-12.

38. Roose, P., Smedes, F., Evaluation of the results of the QUASIMEME lipid intercomparison: the Bligh \& Dyer total lipid extraction method. Mar. Pollut. Bull., 1996, 32 674-80.

39. Cahu, C., Zambonino Infante, J. L., Takeuchi, T., Nutritional components affecting skeletal development in fish larvae. Aquaculture, 2003, 227 245-58.

40. Rousseau, M. , Batista, I., Le Gal, Y., Fouchereau-Peron M., Purification of a functional competitive antagonist for calcitonin gene related peptide action from sardine hydolysate. EJB, 2001, 4 25-32. 


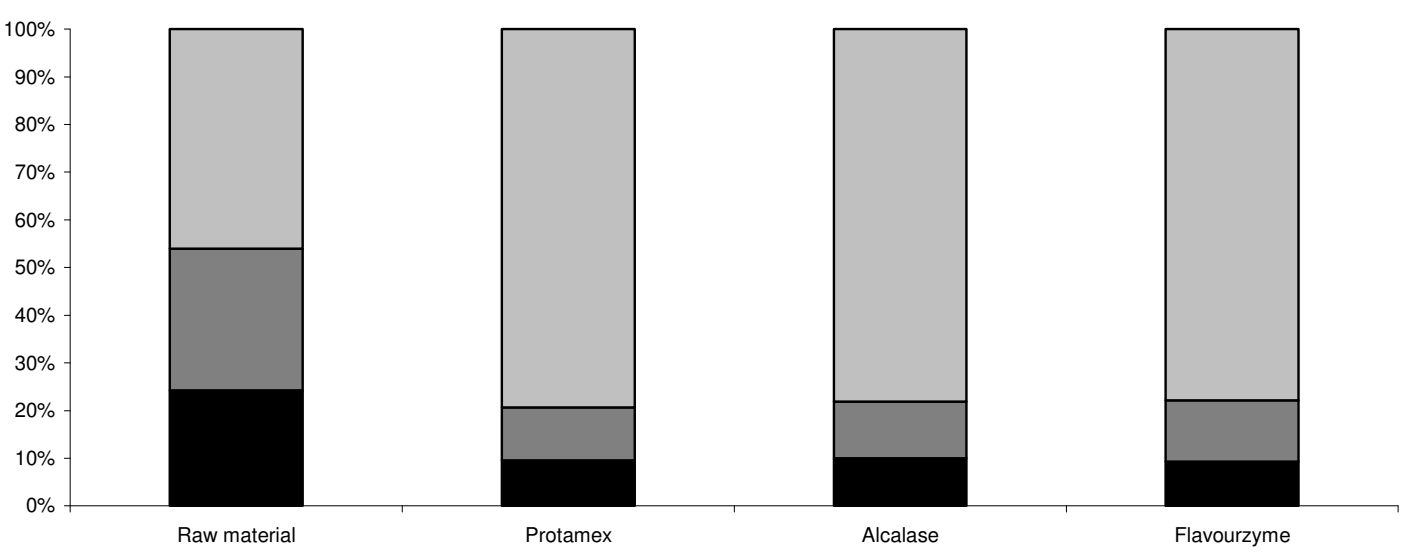

Fig. 1: Dry matter distribution in the different fractions after centrifugation for non hydrolyzed (raw material) and hydrolyzed viscera (Protamex, Alcalase and Flavourzyme). Hydrolysis have been carried out during $24 \mathrm{~h}$, at $\mathrm{pH} 8$ and $50^{\circ} \mathrm{C}$ with 1 volume of water added to raw material. Enzyme concentration were $0.1 \%$ for Protamex and Alcalase and $1.5 \%$ for Flavourzyme.

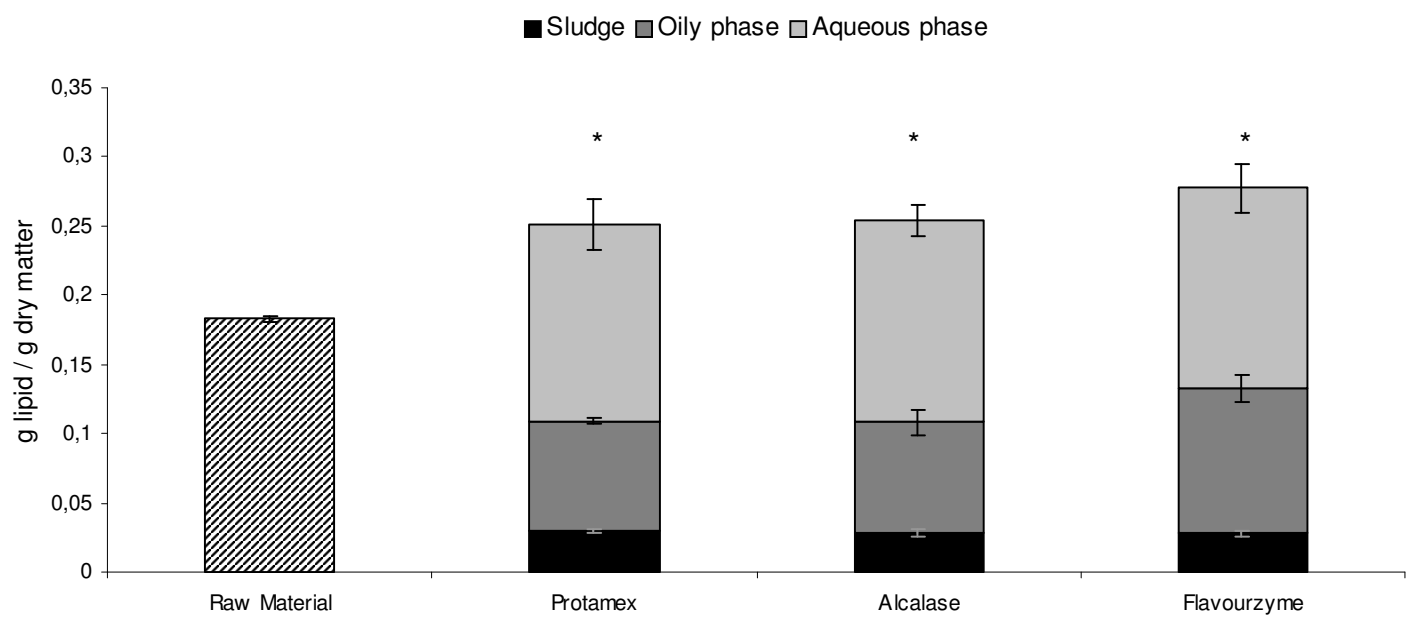

Fig. 2: Lipid distribution among raw material (without hydrolysis) and fractions generated after hydrolysis and centrifugation (*: statistically different at the level of 5\%). Hydrolysis have been carried out during 24 $\mathrm{h}$, at $\mathrm{pH} 8$ and $50^{\circ} \mathrm{C}$ with 1 volume of water added to raw material. Enzyme concentration were $0.1 \%$ for Protamex and Alcalase and $1.5 \%$ for Flavourzyme. Results are expressed as g of lipid / g of dry matter. 
$\square$ Sludge $\square$ oily phase $\square$ Aqueous phase

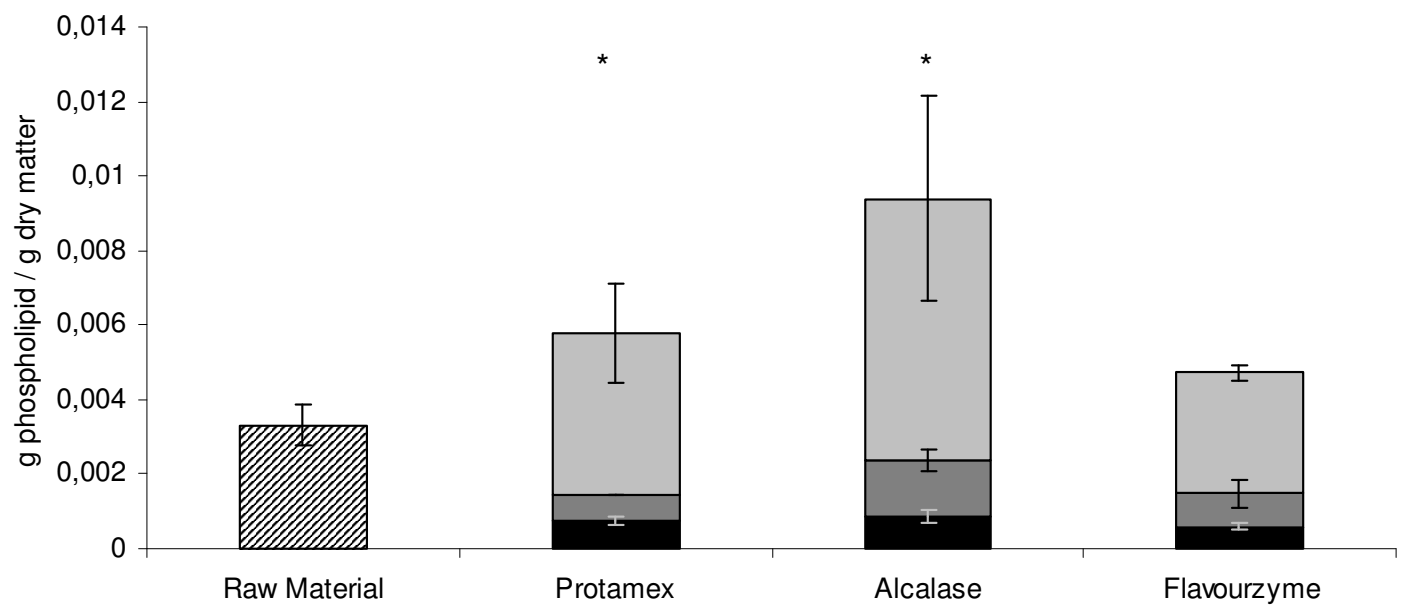

Fig. 3: Phospholipids distribution among raw material (without hydrolysis) and fractions generated after hydrolysis and centrifugation. (*: statistically different at the level of 5\%). Hydrolysis have been carried out during $24 \mathrm{~h}$, at $\mathrm{pH} 8$ and $50^{\circ} \mathrm{C}$ with 1 volume of water added to raw material. Enzyme concentration were $0.1 \%$ for Protamex and Alcalase and $1.5 \%$ for Flavourzyme. Results are expressed as g of phospholipid / g of dry matter. 

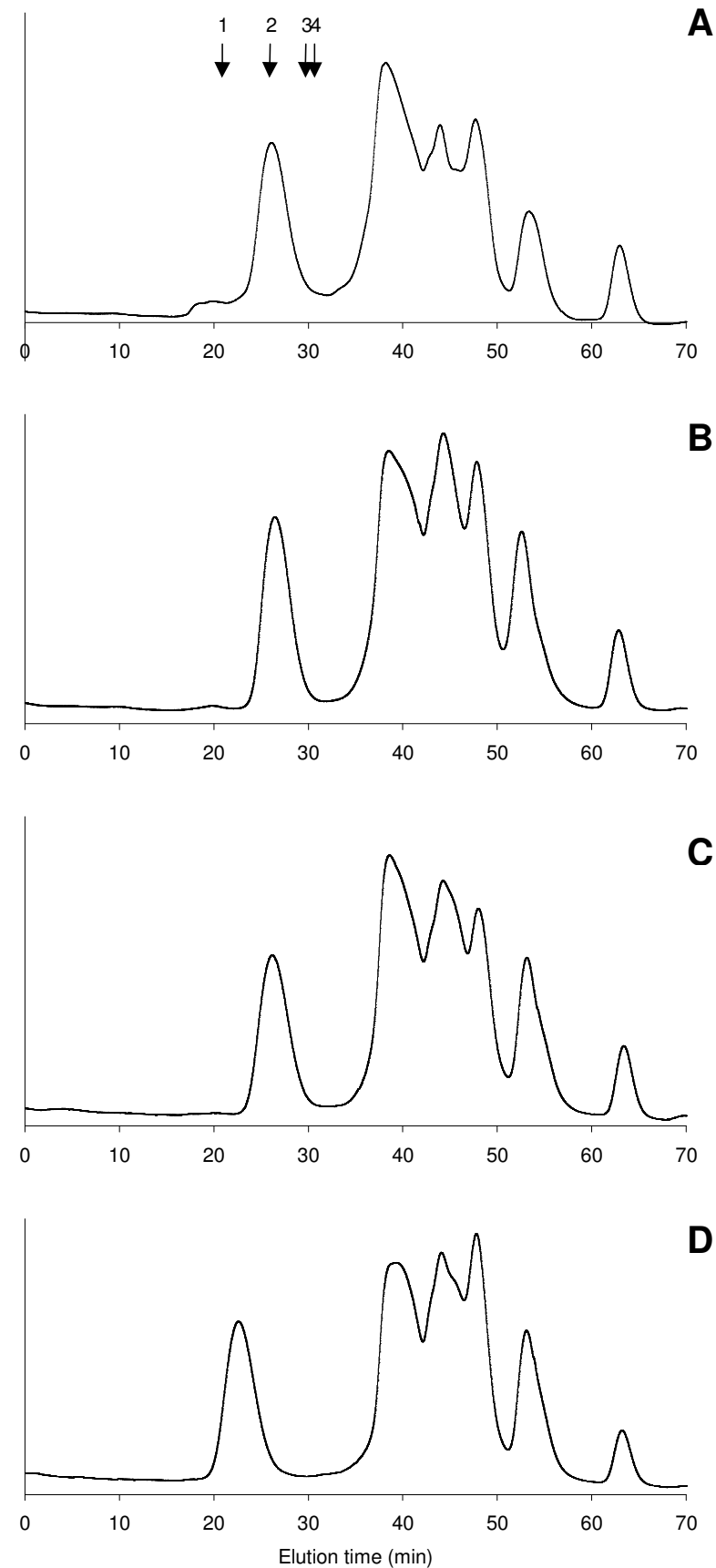

Fig. 4 : Gel filtration chromatograms showing the distribution of FPH fraction molecular weight. A: Raw material (sardine's viscera), B: hydrolyzed with Protamex, C: hydrolyzed with Alcalase, D: hydrolyzed with Flavourzyme. 1: Albumin (67,000 Da); 2: Ovalbumin (43,000 Da); 3: Chymotrypsinogen A (25, 000 Da); 4: Ribonuclease (13,700 Da). 
Table I

Protein recovery and protein content in aqueous phases. Protein recoveries indicate the proportion of total proteins recovered in the soluble phase after hydrolysis. Protein contents are expressed as $g$ of protein per $g$ of dry soluble fraction.

\begin{tabular}{lcc}
\cline { 2 - 3 } & Protein recovery & Protein content \\
\hline Protamex & $61,2 \%$ & 0.54 \\
Alcalase & $60,2 \%$ & 0.54 \\
Flavourzyme & $57,4 \%$ & 0.52 \\
\hline
\end{tabular}

Results are based upon total nitrogen content $* 6.25$. 